\title{
Research into the Application of "Flipped Classroom" in Teaching Management Courses at Colleges and Universities
}

\author{
Yuzhen Wang ${ }^{1, a}$, Chundi Zhao ${ }^{2, \mathrm{~b}}$ and Rengui Zhao ${ }^{3, c^{*}}$ \\ ${ }^{1}$ Chinese Medicine Materials College, Jilin Agricultural University, Changchun, P.R. China \\ ${ }^{2}$ Agricultural College, Jilin Agricultural University, Changchun, P.R. China \\ ${ }^{3}$ Mechanical \& Electrical Engineering College, ChangChun University of Science and Technology, \\ Changchun, P.R. China \\ a349835300@qq.com, b05395854@qq.com, ${ }^{\text {c2 } 2992807490 @ q q . c o m ~}$ \\ *The corresponding author
}

Keywords: Flipped class; Management course; Teaching mode

\begin{abstract}
At present, we have already entered the information age, in which the traditional teaching mode cannot keep pace with the times and is faced with the fate of being eliminated. As a brand-new teaching mode, "flipped classroom" cannot only make up for problems in traditional teaching mode, but also meet the needs of the development of the times. To this end, this paper focuses on how to use "flipped class" in teaching management courses at colleges and universities. With the development of the times, new requirements have also been proposed to talents. And for management talents, they should not only have a solid theoretical foundation, but also strong practical ability. Besides, teaching management courses is to cultivate their practical ability and learning ability as well as improve their comprehensive quality. There are problems with traditional teaching mode, and it also faces challenges from the reality, but "flipped classroom" is a new teaching mode that can meet the needs of the times.
\end{abstract}

\section{Background of Applying "Flipped Classroom" in Teaching Management Courses at Colleges and Universities}

Introduction to "Flipped Classroom". "Flipped classroom", which is sometimes known as "reserved classroom", is essentially to readjust the time inside and outside the classroom so that students master the initiative to learn. At "flipped classroom", teachers no longer spend more time teaching knowledge, but impart knowledge to students in a simple and exquisite way so that more students can complete follow-up study after class. For example, students can gain a deeper understanding of the knowledge taught at class after class, communicate with teachers and other students or read some extracurricular books, etc. so as to comprehensively understand relevant knowledge points.

Teaching Management Courses at Colleges and Universities is Highly Practical. Management courses at colleges and universities generally include management, economics, statistics and operations research, etc., which generally belong to the range of economics and management. One of the purposes of carrying out management courses at colleges and universities is to cultivate students' professional knowledge in management and enable them to have excellent management ability, thus laying a solid foundation for future employment. In addition, there are other purposes of carrying out management courses, i.e., to allow students to manage themselves, including having a clear understanding of themselves and creating interpersonal relationship, etc. It can be said that for college students, management courses cannot only cultivate their professional quality, but also shape their values, outlook on life and even outlook on the world. Due to such characteristics, management courses at colleges and universities are highly practical, so it is suitable for students to learn relevant contents after class, and students can integrate their own feelings during learning so as to better use relevant knowledge.

Problems in Traditional Teaching Mode. College management courses chose "flipped 
classroom" the teaching mode, but also because of the traditional teaching mode has some problems First of all, using the traditional teaching mode, although you can teach students a lot of knowledge, can do everything. But does not pay attention to the cultivation of student's ability. This is because the teacher in the classroom all the time to teach knowledge, class do not pay attention to the cultivation of students' abilities, resulting in many students only have theoretical knowledge, but not the ability to use knowledge, which is not conducive to the employment. Secondly, teachers in the teaching process, is entirely in accordance with the syllabus or textbooks is carried out, it can be said that this is a completely passive mode, the mode of teaching, and the teaching of management courses, which is contrary to the cultivation of students' ability. This teaching model is also very easy to lead students tired, and thus lack of interest in learning. Finally, the teaching time is limited, because the student needs to learn some professional knowledge, every professional courses are only a few hours, but some teachers need also to several classes, so that teachers can only say that the use of the limited time to teach knowledge, to cause the situation where the operator where.

The Challenge of Traditional Teaching Mode. There are many problems in the traditional teaching mode, and the reality has given a lot of challenges to the traditional teaching mode. First, there have been a lot of online learning professional courses, so that students can be their own online learning, so as to achieve the personalized learning and flexibility and so on. Second, learning to access the information more diversified. With the development of science and technology, mobile phones, tablets, computers into millions of households, to our country's major colleges and universities survey found that almost a mobile phone; students can get information at any time through the network. The traditional mode of teaching is not attractive to students; many students turn their attention to the mobile phone, mobile phones in the classroom to become a trend. Second, the university is a full range of teaching reform. In 2014, China promulgated the "guidance on the transformation and development of local colleges and universities". Which clearly indicates that college training should be able to upgrade the industrial transformation and upgrading of services, but also to meet the needs of public services; In 2015, also introduced the "opinions" on deepening the reform of higher education, including a detailed description of personnel training in Colleges and universities should pay attention to practice, pay attention to the cultivation of students' ability.

\section{The Application of "Flipped classroom" in the Teaching of Management Courses in Colleges and Universities}

In the management of university courses, the most important one is the "management". For this, will take "management science" this course as an example, to introduce how to use "flipped classroom" in the course of its teaching ".

Preparation before Class. Want to use "flipped classroom", the most important thing is to do a good job in preparation. For most colleges and universities, the implementation of multimedia teaching, because teachers can teach students to teach knowledge, then one of the preparations is to make micro video. Micro video can transfer knowledge for students, but the flipped classroom is not only the focus of knowledge, there is the interaction between teachers and students and exchanges.

"Management" first introduced Taylor, Taylor is known as the "management" of the father, its contribution to management is very large, and management also cited a lot of Taylor's research. To this end in teaching and Taylor related knowledge, the teacher made the micro video should include the basic situation of Taylor, the academic contribution of his life, so that can lead to the concept of management. In addition, in the course of teaching knowledge, but also should be interspersed with the case, so that students can more clearly how to use knowledge. Of course, the case can be made for students to analyze, in general, to give students 15 minutes to 20 minutes of self-analysis time. Teachers can also teach about the extension of knowledge, generally about 10 minutes or so the best. To learn the knowledge, the need to detect through the relevant exercises, so it is also required to prepare the teacher exercises, the answer to the exercise time of 5 minutes or so is relatively good. Through micro video, students can learn to focus on the content of this lesson, so you do not need to 
take up too much of the class time. In addition, micro video students made by teachers can be repeated to watch, even a course because such things which can't be the class of students will not delay the study, more out of the video before the exam to repeatedly watch.

Class Interaction. College Students' access to information is more diversified, so thinking is relatively active. After the teacher for students to watch the micro video, can let students to express their own thoughts, can combine their actual life and learning, even with their own experience, to talk about their own interpretation of management. This will enable students to find their own management of knowledge, but also allows students to learn how to use management knowledge to answer questions. Moreover, through the interaction of the exchange, to deepen the feelings between teachers and students, so that students in the classroom learning is full of interest.

Thinking after Class. Both teachers and students should be thinking after class. For teachers, it should study the performance of students in the classroom and the expression of the idea, to sum up, so that teachers can improve the teaching ability. For teachers, it should study the performance of students in the classroom and the expression of the idea, to sum up, so that teachers can improve the teaching ability.

\section{Conclusion}

The traditional teaching mode is rigid, cannot meet the needs of the development of the times, and now the technology is developed, the electronic network has become a part of the university students' daily life learning. To this end, it has brought great challenges to the teaching of management courses in Colleges and universities, and the traditional teaching model needs to be changed. Flipped classroom is a new teaching mode, which can save time and increase the frequency of interaction between teachers and students, so that students really know how to use the relevant knowledge of management courses.

\section{References}

[1] X.D. Wang, C.J.Z. Zhang, Research on the application of "flipped classroom" in university teaching, Modern Educational Technology. Vol. 23 (2013) No.08, 11-16.

[2] X.L. Xi: Application research of "flipped classroom" in the teaching of management courses in colleges and universities, Nanyang Normal University. Vol. 11 (2015) 64-67.

[3] J.Y. Hu, J.P. Jiang, The application of flipped classroom in the teaching of software course-taking undergraduate "two dimensional animation" curriculum as an example, Chinese Distance Education. Vol. 03 (2016) 45-51.

[4] N. Liu, J. Wan, C. Yang, D.L. Zhang, J. Li, Research on the application of the flipped classroom teaching mode in the general course of university-taking "DIY video production" as an example, China Education Information Technology. Vol. 16 (2016) 61-63+75.

[5] L.Q. Ha, Application of flipped classroom model on management courses in colleges and universities, Era of Education. Vol. 17 (2016) 73-74. 